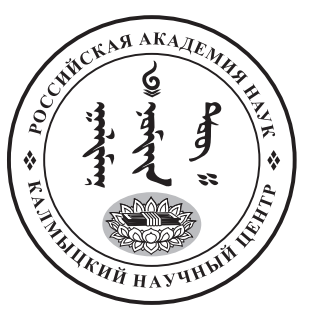

Published in the Russian Federation

Oriental Studies (Previous Name: Bulletin of the Kalmyk Institute

for Humanities of the Russian Academy of Sciences)

Has been issued as a journal since 2008

ISSN: 2619-0990; E-ISSN: 2619-1008

Vol. 14, Is. 4, pp. 858-867, 2021

Journal homepage: https://kigiran.elpub.ru

УДК / UDC 28:398.88:82-141

DOI: $10.22162 / 2619-0990-2021-56-4-858-867$

\title{
Некоторые религиозные термины, хадисы и аяты в башкирских мунаджатах
}

Ахат Губаевич Салихов ${ }^{1}$, Гульназ Мирфатовна Гиззатуллина ${ }^{2}$

${ }^{1}$ Институт истории, языка и литературы Уфимского федерального исследовательского центра РАН (д. 71, пр. Октября, 450054 Уфа, Российская Федерация)

кандидат исторических наук, ведущий научный сотрудник

iD 0000-0002-7994-4711. E-mail: ahatsalihov@mail.ru

${ }^{2}$ Институт истории, языка и литературы Уфимского федерального исследовательского центра РАН (д. 71, пр. Октября, 450054 Уфа, Российская Федерация)

аспирант

iD 0000-0002-0352-776X. E-mail: gizzat-gm@mail.ru

\author{
(C) КалмНЦ РАН, 2021 \\ (C) Салихов А. Г., Гиззатуллина Г. М., 2021
}

Аннотация. Введение. В устном народном творчестве и письменных литературных памятниках башкирского народа существует особый вид музыкально-поэтического творчества лиро-эпического характера, который вобрал в себя духовные поиски и обращения к Богу. Этот жанр называется «мунаджат». Целью данной статьи является анализ некоторых аятов, хадисов и религиозных терминов, использованных в башкирских мунаджатах. Материаль и мето$\partial b l$. Основным источником исследования являются образцы религиозной поэзии, взятые из очередного тематического тома свода «Башкирского народного творчества». Выявлено более 1500 примеров, часть из которых использована в данной работе. Применен системный и сравнительный анализ, историко-типологический метод исследования. Результаты. К исследованию мунаджатов обращались многие башкирские ученые. В своих работах они неоднократно обращались к изучению особенностей рассматриваемого жанра, основным признаком которого является наличие в нем религиозных мотивов, сюжетов и обращение с мольбой к Аллаху. С начала 90-х гг. ХХ в. мунаджаты переживают второе рождение. В широкий обиход вернулись старинные варианты этого вида фольклора. В различных регионах Башкортостана продолжают возникать и распространяться их новые виды, сочиненные нашими современниками. В ходе изучения поэтических произведений было выявлено более полутора тысяч примеров с использованием мусульманских терминов, аятов и хадисов. Некоторые из них были рассмотрены в данной статье. Bblвoдbl. Исследование позволило раскрыть и показать особенности использования религиозных сюжетов, терминов и мотивов в башкирских мунаджатах. Некоторые слова и словосочетания были изменены на более приемлемый народу язык, при этом 
сохраняя арабоязычное клише. В свою очередь употребление религиозной лексики обогатило башкирский язык и литературу.

Ключевые слова: мунаджаты, исполнительство, духовность, башкирский фольклор, башкирская поэзия, мусульманская поэзия, старопечатные книги, восточные рукописи, письменные источники

Благодарность. Исследование проведено в рамках государственной субсидии - проект «Духовная культура тюркских народов Южного Урала» (номер госрегистрации: AАAА-A17-117040350082-3).

Для цитирования: Салихов А. Г., Гиззатуллина Г. М. Некоторые религиозные термины, хадисы и аяты в башкирских мунаджатах // Oriental Studies. 2021. T. 14. № 4. С. 858-867. DOI: 10.22162/2619-0990-2021-56-4-858-867

\title{
Revisiting Some Religious Terms, Hadiths and Ayahs in Bashkir Munajats
}

\author{
Akhat G. Salikhov ${ }^{1}$, Gulnaz M. Gizzatullina ${ }^{2}$
}

${ }^{1}$ Institute of History, Language and Literature of the Ufa Federal Research Centre of the RAS (71, Oktyabrya Ave., 450054 Ufa, Russian Federation)

Cand. Sc. (History), Leading Research Associate

iD 0000-0002-7994-4711. E-mail: ahatsalihov@mail.ru

${ }^{2}$ Institute of History, Language and Literature of the Ufa Federal Research Centre of the RAS (71, Oktyabrya Ave., 450054 Ufa, Russian Federation)

Postgraduate Student

iD 0000-0002-0352-776X. E-mail: gizzat-gm@mail.ru

(C) KalmSC RAS, 2021

(C) Salikhov A. G., Gizzatullina G. M., 2021

\begin{abstract}
Introduction. In the oral popular art and written literary monuments of the Bashkir people, there is a special musical-poetic genre of the lyric-epic and religious character, which is called munajat. This article aims to analyze some of the ayats, hadiths, and religious terms used in the Bashkir munajats. Materials and methods. Samples of religious poetry borrowed from a thematic volume of the Bashkir folk art compendium were used as the main source of the research data. Over 1,500 examples have been identified, some of which are used in this article. A systematic and comparative analysis and a historical-typological research method were employed for the analysis of the material. Results. Many Bashkir scholars were among the students of the munajats. In their works, they often focused on the main features of the genre, such as religious motifs, plots, and appeals to Allah that they contain. Since early 1990s, the munajats have been experiencing a rebirth: old versions have returned to become popular again; also, new types, composed by our contemporaries, have emerged, and spread in various regions. The study resulted in identifying over one and a half thousand examples containing Muslim terms, ayats, and hadiths; some of them have been included in this article. Conclusions. The present study shows the peculiarities of the use of religious subjects, terms, and motifs in the Bashkir munajats. Some words and phrases were changed to adapt to the popular usage, while preserving the Arabic cliché. In its turn, the use of religious vocabulary enriched the Bashkir language and literature.

Keywords: munajat, performance, spirituality, Bashkir folklore, Bashkir poetry, Muslim poetry, early printed books, Oriental manuscripts, written sources

Acknowledgements. The reported study was funded by government subsidy, project no. AAAA-A17-117040350082-3 'Turkic Peoples of the Southern Urals: Spiritual Culture'.

For citation: Salikhov A. G., Gizzatullina G. M. Revisiting Some Religious Terms, Hadiths and Ayahs in Bashkir Munajats. Oriental Studies. 2021. Vol. 14 (4): 858-867. DOI: 10.22162/2619-09902021-56-4-858-867
\end{abstract}




\section{Введение}

Мунаджат, являющийся одним из музыкально-поэтических жанров религиозной литературы и фольклора, широко распространен среди мусульманских народов Урало-Поволжья. Название жанра отражает его содержание. Оно происходит от арабского слова مناجاة мунаджат 'тайная беседа') [Гиргас 2006: 785], в башкирском языке означающего «мольбу к Аллаху», «стихи с обращением к Аллаху» [Киреев 1981: 154].

Бытование указанного жанра среди башкир связано с принятием ислама. В них отражается широкий круг духовных и нравственно-дидактических аспектов народного мировоззрения, также параллельно даются сведения о религиозных законах (исламская юриспруденция), в частности о столпах и основах религии.

\section{Цель и задачи исследования}

Целью данной статьи является изучение и выявление особенностей использования аятов (стихов и предложений, выражающих законченные мысли в сурах Корана), хадисов (преданий о словах и действиях Пророка Мухаммеда) и религиозных терминов, использованных в башкирских мунаджатах.

\section{Материалы и методы}

Для проведения исследования были привлечены мунаджаты, собранные среди башкир в различные годы во время фольклорных экспедиций. В качестве источника был привлечен том «Башкирского народного творчества», изданный в 2018 г. в уфимском издательстве «Китап» [БНТ 2018]. Авторы статьи выявили более 1500 примеров, в которых использовались различные сюжеты, мотивы, термины, аяты и хадисы. Для статьи были отобраны наиболее яркие образцы, соответствующие заявленной теме исследования.

При изучении материалов были применены системный и сравнительный анализ, историко-типологический метод.

Использование термина «мунаджат» в литературе и фольклоре

По мнению С. Р. Усеиновой, исследовавшей диван ал-Бура'и, достаточно рас- пространенный в арабской религиозной поэзии термин «мунаджат» (букв. 'тайная беседа') является одним из жанровых обозначений касыд. Среди разновидностей касыд она выделяет хвалебную поэзию в честь Пророка Мухаммеда (мада'их набавийа), обращения с мольбой к Богу (ибтихалат или тадарру'ат), вместо которых часть ученых используют более распространенный термин «мунаджат». Для обозначения подобных стихотворений встречаются и другие термины [Усеинова 2014: 48-49].

Как видим, в башкирских религиозных стихотворных текстах используется наиболее распространенный термин «мунаджат». В то же время жанр с течением времени трансформировался под влиянием культурных традиций башкирского народа и стал неотъемлемой частью фольклора. Жанр сам по себе малоизучен, но вместе с тем есть ученые, внесшие определенный вклад в исследование мунаджатов.

Большой вклад в изучение тематики, поэтики и мелодики башкирских мунаджатов внесла Г. С. Галина, опубликовавшая по указанной теме монографию [Галина 2006].

Известный ученый С. А. Галин рассматривает мунаджаты как часть баитов, имеющих назидательное, воспитательное значение (см.: [Султангареева 2018: 390]). Однако в другом своем научном труде мунаджаты он, наряду с социально-бытовыми баитами, относит к лирическому фольклорному жанру [Галин 2004: 115].

Некоторые ученые, изучавшие данный жанр, придерживаются мнения о религиозно-книжном происхождении мунаджатов [Салихов, Абдрафикова, Искандарова 2017: 157-158].

По мнению литературоведа Г. С. Кунафина, мунаджат можно перевести как «религиозный гимн», «хвала Богу», который в художественной литературе и фольклоре является поэтическим произведением дидактического характера, посвященным морально-этическим и философским вопросам. По идейно-художественной природе он сочетает элементы панегирической и дидактической поэзии, драматический пафос, 
религиозно-нравственные и светско-реалистические начала, поэтому жанр носит синкретический характер. Ученый полагает, что время появления мунаджатов в башкирской поэзии очень трудно установить, но на появление данного жанра поэзии оказали влияние суры, аяты и хадисы, произведения восточной религиозно-мистической литературы, различные комментарии и толкования религиозных постулатов [Кунафин 2011: 118-130].

Г. С. Кунафин также отмечает связь мунаджатов с некоторыми эпическими произведениями, такими как «Кисса-и Юсуф», «Бузйегет», «Тахир и Зухра». На становление жанра мунаджат большое влияние оказал суфизм. К данному жанру активно обращались поэты XIX в. В конце указанного века данный жанр претерпел изменения: усилились вопросы патриотизма, просвещения, нравственности, что позволило расширить его функциональную систему [Кунафин 2011: 118-130].

Как пишет известный башкирский ученый А. Н. Киреев, стихотворные части башкирских романтических эпосов сэсэны (сказители) часто исполняли на мелодии духовных стихов - мунаджатов. Подобные эпосы вошли в основной репертуар народа через книжные источники, в них отсутствовала героика, проблематика была ограничена описанием трагической любви. Эти произведения были окрашены религиозной тематикой. Большую роль в их распространении играли тэлэкси и наурызсы, которые ходили по домам и исполняли мунаджаты. А. Н. Киреев также обратил внимание на то, что в сюжетах мунаджатов присутствуют мотивы покорности, жалости, пессимизма [Киреев 1970: 216-217].

Более широкое научно-теоретическое освещение и анализ жанр получил в трудах Р. А. Султангареевой, где дается классификация жанра по функционально-тематическим и отчасти содержательным признакам, анализируются истоки происхождения, поэтико-стилевые, исполнительские особенности и функциональная специфика. Она дает следующую классификацию:
1) мунаджаты о смерти и поминовениях духов предков;

2) мунаджаты, посвященные восхвалению Аллаха Единого и Одного;

3) мунаджаты, восславляющие пророков, святых, вероучителей;

4) мунаджаты, посвященные религиозному образованию и прославляющие ученость, знания, исламское вероучение;

5) мунаджаты, посвященные религиозным праздникам, торжествам;

6) мунаджаты о неволе и изгнаниях (зиндан мөнджәтторе);

7) мунаджаты из эпических сказаний, хроник [Султангареева 2018: 390].

В медресе изучались арабский язык и литература, а также сочинения по арабской поэзии, заучивались их отдельные образцы. Выпускники медресе начали создавать в башкирской литературе касыды, газели, пользоваться метрикой аруза, что, несомненно, повлияло и на фольклор, и на литературу [ИБЛ 1990: 495].

У крымских татар также распространен этот вид фольклора, и приводятся нижеследующие виды илахи (восхваление Bceвышнего):

1) таухид (единобожие);

2) вакуф или вукуф (остановка для молящегося);

3) зикр (восхваление Аллаха);

4) сув селя (омывание);

5) киев ве келин (жених и невеста);

6) Мухаммед (восхваление Пророка Мухаммеда, мир Ему и благословение).

У них также отдельно выделяется Мевлюд - повествование о жизни Пророка Мухаммеда, который сформировался под влиянием празднования дня рождения Пророка Мухаммеда [Туймова 2008: 13-15].

\section{Отражение принципа единобожия в мунаджатах}

Основополагающим принципом ислама является توحيد таухид - догмат о единственности и единстве Аллаха, убеждение в его сущности, качествах и действиях. Она выражается словами шахада, части которого широко использованы в фольклорных сочинениях, более того, отражены в их названиях. Например: 
«Лә илаһи иллә Алла»ны,

Телдән һалмайык бер заман, «Лә илаһи иллә Алла»нан Айырылһак, шул яман.
'Постоянно нужно повторять:

«Нет бога, кроме Аллаха».

Плохо, если не будем говорить:

«Нет бога, кроме Аллаха».'

(Здесь и далее перевод авторов) [БНТ 2018: 48].
В них в качестве литературного клише удачно используется часть шахады لَ إلَإِلَّ ألَّ Ля илахи илла Аллах. В качестве при- мера можно привести отрывок другого варианта вышеуказанного произведения:

\author{
«Лә илаһи иллә Алла»ла \\ Ғәри көрси бас̧жысы. \\ «Лә илаһи иллә Алла» - \\ Һигез ожмах аскысы.
}

\author{
'«Нет бога, кроме Аллаха» — \\ Это ступени к божьему трону. \\ «Нет бога, кроме Аллаха» - \\ Это ключи от восьми ворот рая’ [БНТ 2018: 49].
}

Виды обращений к Всевышнему в мунаджатах

В текстах мунаджатов часто встречаются обращения, мольбы, просьбы к Аллаху. Это наиболее ярко отражается в истории

\author{
Ғәфү әйлә, Раббандм! \\ Эй, Хозайым, шөкөр кылам \\ Йә, иләһи \\ Рәхим кыл, йә, Рәхималла \\ Рәхим кылгыл, Илаһым \\ Ғәфу кылгыл, Илаһымм
}

происхождения мунаджатов. В образцах народного творчества рассматриваемого жанра можно встретить достаточно большое количество материала для иллюстрации вышесказанного:

‘Прости, Господи!' [БНТ 2018: 37].

‘Благодарю тебя, Господи!' [БНТ 2018: 38].

'О, Боже' [БНТ 2018: 38].

‘Смилуйся, о, Милостивый’ [БНТ 2018: 39].

‘Окажи милость, Господи’ [БНТ 2018: 44].

‘Прости, мой Аллах’ [БНТ 2018: 44]. дай»:

В некоторых сочинениях для обозначения Аллаха используется персидское слово «Ху-

Эй, Хозайымл, бер Хозайым,

Эй, Хозайым, бер Хоз̧ай!

Донъя, ахирәт мәксүденән

Айырма һин, бер Хозай.

Эй, Хозайьмм, Хоза Кәрим,

Һинең рәхмәтеңъә карыйм.

Ювиһә мин кайза барыйм?

Шәфәгәт кыл, йә, Рәсүлуллаһ!

В некоторых случаях они применяются параллельно: Эй, Хозайым, Раббымм, Аллам 'О, мой Худай, мой Раббе, мой Аллах' [БНТ 2018: 38].
'О, мой Господь, единственный Господь, О, мой Господь, единый Господь,

Не отделяй меня, Господь,

От целей мирского и вечного.

О, Господи, Великий Бог,

Жду милости твоей.

Иначе мне куда пойти,

Заступись, о, божий пророк!' [БНТ 2018: 36].

Нередко в мунаджатах используется тюркское слово тәңре ('бог’). В некоторых местах в переводах широко известных мусульманских формулировок оно заменяет слово «Аллах»: 
Тәнре бар, Тәнре бер

Кем яһаван Ерзе, Күкте,

Кем яһай ала бойзай?

Йә, яһай тәмле бойзай,

Булмаһа Тәщре, Хоз̆ай?

Күңел аскыстары Тәнре кульнда

Тәңрем, рәхмәтеңз туймаһам

Йәнем сыкканда нисек сызармын, Яраткан Тәнрем, Үзенц ярзам бир
‘Бог есть, бог един’ [БНТ 2018: 49].

'Кто создал землю, небо,

Кто может создать пшеницу?

Кто создаст вкусную пшеницу,

Если не будет Тенгри, Худая?' [БНТ 2018: 53].

‘Ключи души в руках Тенгри’ [БНТ 2018: 57].

‘Не насыщусь милостью Тенгри’ [БНТ 2018: 72].

'Как выдержу исход души,

Создатель-Тенгри, окажи милость' [БНТ 2018: 164].

\section{Идеи просветительства и использова- ние хадисов в мунаджатах}

Идея просветительства была присуща и творчеству башкирских поэтов-просветителей XIX-XX вв., таких как Мифтахетдин Акмулла, Мухаметсалим Уметбаев, Хибатулла Салихов, Гарифулла Кииков. В их творчестве переплелись философские, нравственные, этические и религиозные воззрения [ИБЛ 2012: 322-323, 337-339, 354-355, 371].

Идеи просветительства особенно ярко проявились в стихотворениях М. Акмуллы. Среди башкир было широко распространено его религиозно-дидактическое сочинение «Насихат» («Назидания») в рукописной и устной форме, сюжеты которого имеют параллели с мунаджатами [Салихов 2020: 74-83].

Мусульманские ученые большое внимание уделяли получению людьми знаний и образования. В частности, для обоснования необходимости изучения наук мусульманские богословы приводили хадисы. Хадисы - это слова, дела, молчаливое одобрение, нравственные качества и отличительные внешние особенности пророка Мухаммеда (мир Ему и благословение) [Хадис 2014: 11]. Так, в сочинении Абу Хамид Мухаммад аль-Газали ат-Туси «Ихйа' 'улум ад-дин» встречается хадис: «Ищите знания, даже отправляясь в Китай» [Аль-Газали 2011: 53].

Достаточно интересным является мунаджат «Белем алыу кәрәк һәр бер уғылкыз̧ға» ('Учиться нужно каждому юноше и девушке'), в котором приводится достоверный, но слабый хадис со словами Пророка о необходимости получать знания где бы то ни было, даже если нужно будет идти в Китай:

Белем альуу кәрәк һәр бер увыл-кыз̧ва,

Кәрәк икән барып вилем ал һин Кытайва.

Хәзис шәриф - тел белеме кәлимәттән, әлә көлли мөслими ва мөслиматтан.

Расүлебез дйткән микән бу хәзичне

Савәзатле кылмак өсөн һар бер эине

'Каждому нужно знание брать, Даже если в Китай за наукой идти. Хадис-шариф - знания от слов Для каждого мусульманина и мусульманки. Пророк сказал, видно, этот хадис

Во имя благополучного вершения каждого дела...' [БНТ 2018: 143].

Несмотря на то, что данный хадис («Ищите знания, даже если придется отправиться в Китай») считается слабым, он является общеизвестным и распространенным в мусульманских регионах, в том числе и в Урало-Поволжье.

В исламе невежество является порицаемым явлением, восхвалялось получение знаний, его применение во благо обществу. Как показывает пример, смысловая нагрузка хадиса была удачно использована в одном из мунаджатов.

Знаток устно-поэтического творчества А. Н. Киреев выявил тематику башкирских мунаджатов, в которых встречаются и мирские темы, дидактические мотивы, нравственные проблемы. В шакирдовских мунаджатах есть сюжеты, призывающие к просвещению, знаниям. Одним из видов религиозных мунаджатов является саде (восхваляющие стихотворение), в настоящее время остающееся вне внимания 
исследователей. По мнению А. Н. Киреева, мунаджаты вошли в фольклор вместе с религиозными сюжетами баитов, поэтому они являются близкими жанрами [Киреев 1981: 153-154].

\section{Мәхидр еренә барганда, \\ Шафавәтсе Мөхаммат. \\ Аллаһыма салливәла \\ Сәйедина Мехаммәт!}

Сәләм булсын сән, йа Рәсүлуллаһ!

Здесь восхваляется и произносится мольба к Посланнику в надежде на заступничество и близость к нему в Судный день. Салават (благословение) является причиной принятия молитв, чистоты веры и благополучия. В средневековой арабской мусульманской поэзии отражалась важнейшая функция пророка Мухаммеда - заступничество перед Богом (шафа'а) [Усеинова 2014: 39-41]. В башкирских мунаджатах встречается обращение к Пророку, восхваление его деяний.

Мунаджаты создавались авторами, которые хорошо знали религиозные каноны, литературу, содержание аятов и многое другое, тесно связанное с основами ислама:

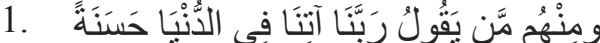

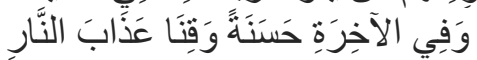

Аллаһыма раббанә атинд фиддүниә

Ахирәте, хәсәнате,

Хозайым, я, Рабби! [БНТ 2018: 158].

'Среди людей есть такие, которые обращаются своими искренними сердцами к Богу, прося даровать им добро в ближайшей и в последующей жизни и спасти их от муки огненной' [Аль-Мунтахаб 2012: 29].

$$
\text { 2. وَالْعَصْرِ }
$$

Үәлгасрины укывыз [БНТ 2018: 195].

'Клянусь временем, в которое происходит много чудесных явлений и назиданий...' [Аль-Мунтахаб 2012: 567].

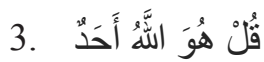

Көллөхәт [БНТ 2018: 52] или

«Колиоу» теле [БНТ 2018: 155].

'Скажи, о Мухаммад, тем, которые, издеваясь, сказали, чтобы ты описал им твоего Господа: «Он - Аллах Единый и един-
Далее в качестве примера практического применения изречения Пророка о чтении салавата صَتلَََات 'благословение, молитва Пророку' можно привести следующие строки:

'Когда придем на площадь Отчета, То заступником будет Мухаммед.

Аллах, благослови

Господина Мухаммеда' [БНТ 2018: 61].

Мир тебе, о Пророк Аллаха!' [БНТ 2018: 91].

ственный. И нет у Него сотоварищей...' [Аль-Мунтахаб 2012: 570].

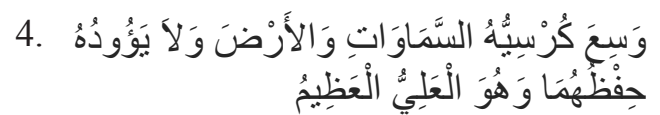

Укыйык «Аятел Көрси»не,

«Хивзөһөма» тиган һүззе [БНТ 2018: 123].

'... Трон Аллаха, Его знания и Его власть обширнее небес и земли, и не тяготит Его охрана их. Поистине, Он - Всевышний, Единый и Великий' [Аль-Мунтахаб 2012: 39].

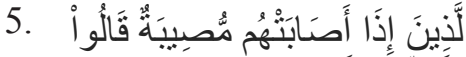

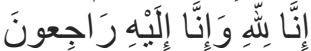

Иншааллаһыу разивун [БНТ 2018: 196].

'....тех, которые, когда постигнет их бедствие, верят, что благо и бедствие от Аллаха Вездесущего, и говорят: «Поистине, мы во власти Аллаха, и лишь к Нему мы возвратимся! Мы благодарим Его за блага и терпим бедствия и при награде, и при наказании' [Аль-Мунтахаб 2012: 22].

\section{Мусульманские предания в мунаджа- $\operatorname{Tax}$}

В мунаджатах очень часто используются сюжеты преданий о жизни пророков. Как известно, до 20-х гг. ХХ в. в тюркоязычных издательствах России в большом количестве печатались различные варианты сочинения «Киссас аль-анбия» («Житие пророков»). Они широко использовались в мусульманских образовательных учреждениях и были популярны среди населения.

Так, в башкирские мунаджаты попали предания о пророках Адаме, Хаве, Якубе, Юнусе и других: 
Атам - Әззм, Анам - һауа,

Альип сыкты вүмер тәүза

Укыl, Сиз̧ыкыцй, Ясинды

Сәләм булсын сән, йә Рәсүлуллаһ!
'Отец - Адам, мать - Хава,

Первые увидели жизнь...’ [БНТ 2018: 169].

‘Ситдыки, читай Ясин’ [БНТ 2018: 161].

‘Приветствие тебе, о Пророк Аллаха’ [БНТ 2018: 91].
В некоторых произведениях перечисляются деяния пророков. Так в сочинении «Пәйғәмбәрзәр тураһында» («О пророках»)

...Якуп пәйзәмбәр Алла каршында

Балаһы өсөн көйгәнен һөйләр.

Йосоп пәйхәмбәр Алла каршында

Каруанга hатылыл киткәнен һөйләр.

Ибраһим пәйвәмбәр Алла каршында

Уттан гөл-бакса булганын һөйләр.

Сөләймән пәйгәмбәр Алла каршында

Ете кат күккә ашканын һөйләр.

Юныс пәйгәмбәр Алла каршында

Ете кат үлеп терелгәнен һөйләр.

(Ғ)Айса пәйвәмбәр Алла каршында

Дүрт кат күккә ашканын һөйләр.

Әйүп пәйзәмбәр Алла каршында

$Y_{3}$ итенән корт эйгәнен һөйләр.

Юныс пәйгәмбәр Алла каршында

Балькк карынындда ятканын һөйләр.

Һәр бер пәйхәмбәр Үз хәлен һөйләр,

Үз өммәтенд ярлькау теләр.

Насип ит, Аллам, без̧ колларыңды

Йәннәт эсендә бергә бульрва

В этих строках рассказывается, что пророки Якуб, Юсуф, Ибрахим, Сулейман, Юнус, Иса (Иисус), Аюб расскажут перед Всевышним о том, через какие испытания они прошли, также будут просить о помиловании своего народа. Эти истории есть в Священном Коране как коранические предания. Они приведены и направлены на читателя как воспитывающие рассказы. Поэтому свойства мунаджата как дидактического жанра здесь особенно видны, потому что даются короткие сюжеты из жизни пророков авраамических религий, тем самым обогащаются знания читающего.

\section{Выводы}

Анализ мунаджатов, являющихся одним из наиболее распространенных видов башкирского народного творчества, показывает, описываются предстоящие действия пророков перед Аллахом.

\section{‘...Пророк Якуб пред Аллахом}

Расскажет, как о дитя горевал.

Пророк Юсуф пред Аллахом

Расскажет, как каравану продан был.

Пророк Ибрахим пред Аллахом

Расскажет, как огонь садом стал.

Пророк Сулейман пред Аллахом

Расскажет, как на семи небесах парил.

Пророк Юнус пред Аллахом

Расскажет, как после семи смертей оживал.

Пророк Иисус пред Аллахом

Расскажет, как на четырех небесах витал.

Пророк Аюб пред Аллахом

Расскажет, как проказой болел.

Пророк Юнус пред Аллахом

Расскажет, как в животе рыбы обитал.

Каждый Пророк про дела свои расскажет,

Своей общине прощение пожелает.

Предопредели, Аллах, нам, твоим рабам,

Быть вместе в Раю’ [БНТ 2018: 93].

как специфичный жанр несет в себе религиозную идею, тем самым обучая, наставляя и воспитывая людей.

Рассмотрены образцы мунаджатов, которые показывают особенности использования религиозных мотивов в поэтических произведениях. Кроме того, можно отметить искажение арабских фраз, названий книг, слов при передаче в устной и письменной форме. Наряду с религиозными терминами, понятиями и сюжетами в рассмотренных мунаджатах поднималась и тема просвещения, которая, в общем, не была чужда догматам ислама. Исследование позволило выявить использованный в мунаджатах ряд аятов и хадисов, сюжетов популярных религиозно-мистических произведений. Они умело и уместно вплетены в стихотворную канву повествований. 


\section{Литература}

Аль-Газали 2011 - Абу Хамид Мухаммад аль-Газали ат-Туси. Ихйа' 'улум ад-дин (Возрождение религиозных наук): в 10 т. Т. 1 / пер. с араб. яз. И. Р. Насырова и А. С. Ацаева. 2-е изд. Махачкала: Нуруль иршад, 2011. 424 с.

Аль-Мунтахаб 2012 - Аль-Мунтахаб фи Тафсир аль-Кур'ан аль-Карим. Толкование Священного Корана на русском языке: перевод с арабского языка. Казань: Идель-Пресс, 2012. $638 \mathrm{c}$.

БНТ 2018 - Башкирское народное творчество. T. XV: мунажаты / сост., авт. вступ. ст. и коммент. Р. А. Султангареева. Уфа: Китап, 2018. 296 с. (На башк. яз.).

Галин 2004 - Галин С. А. Башкирское народное творчество. Уфа: Китап, 2004. 392 с. (На башк. яз.).

Галина 2006 - Галина Г. С. Башкирские баиты и мунажаты: тематика, поэтика, мелодика. Уфа: Изд-тво БИРО, 2006. 186 с.

Гиргас 2006 - Арабско-русский словарь к Корану и хадисам / В. Ф. Гиргас. СПб.: Диля, 2006. 928 с. (На араб. и рус. яз.)

ИБЛ 1990 - История башкирской литературы: в 6 т. Т. 1: Средневековый период / отв. ред. Г. Б. Хусаинов. Уфа: Башкнигоиздат, 1990. 609 с. (На башк. яз.).

ИБЛ 2012 - История башкирской литературы: в 4 т. / гл. ред. М. Х. Надергулов. Т. 1: С древнейших времен до начала XX века / отв. ред. Г. Б. Хусаинов. Уфа: Китап, 2012. 560 с.

Киреев 1970 - Киреев А. Н. Башкирский народный героический эпос. Уфа: Башкирск. кн. изд-во, 1970. 304 с.

\section{References}

Abū Hāmid Muhammad al-Ġazālīy aț-Ṭūsiyy. The Revival of the Religious Sciences. In 10 vols. Vol. 1. I. R. Nasyrov, A. Atsaev (transl.). $2^{\text {nd }}$ ed. Makhachkala: Nurul Irshad, 2011. 424 p. (In Russ.)

An Interpretation of the Holy Quran: Arabic-to-Russian Translation. Kazan: Idel-Press, 2012. 638 p. (In Russ.)

Galin S. A. Bashkir Folklore. Ufa: Kitap, 2004. 392 p. (In Bash.)

Galina G. S. Bashkir Baits and Munajats: Themes, Poetics, Melodies. Ufa: BIRO, 2006. 186 p. (In Bash.)

Ganiev I. (comp.) Hadith: A Guidebook. St. Petersburg: Dilya, 2014. 272 p. (In Russ.)
Киреев 1981 - Киреев А. Н. Башкирское народное устно-поэтическое творчество: учеб. пособ. Уфа: БашГУ, 1981. 232 с. (На башк. яз.).

Кунафин $2011-$ Кунафин Г. С. Башкирская поэзия XIX - начала XX веков: вопросы жанровых и идейно-художественных особенностей. Уфа: АН РБ, Гилем, 2011. 480 с.

Салихов, Абдрафикова, Искандарова 2017 Салихов А. Г., Абдрафикова Г. Х., Искандарова $C$. $A$. Мунаджаты Татышлинского района Республики Башкортостан // Археография Южного Урала: Документальное наследие революции 1917 года: материалы XVII Всероссийской научно-практической конференции / под ред. А. Б. Юнусовой. Уфа: Мир печати, 2017. С. 157-164.

Салихов 2020 - Салихов А. Г. Арслан-Амекачевский (Унгаровский) вариант «Назиданий» Мифтахетдина Акмулла // Проблемы востоковедения. 2020. № 3 (89). С. 74-83.

Султангареева 2018 - Султангареева P. A. Башкирский фольклор: семантика, функции и традиции: Т. 1: Миф. Обряд. Танец. Сказительство. Шаманский, религиозный, музыкальный фольклор. Современные традиции. Уфа: Башк. энцикл., 2018. 520 с.

Туймова 2008 - Туймова Г. Р. Религиозные музыкально-поэтические жанры в традиционной музыке крымских татар: мавлид и иляхи: автореф. дисс. ... канд. искусст. М., 2008. 22 c.

Усеинова 2014 - Усеинова С. Р. Проблемы определения и периодизации арабской религиозной поэзии // Вестник Санкт-Петербургского государственного университета. Сер. 13. 2014. Вып. 2. С. 39-52.

Хадис 2014 - Хадис: учебное пособие / сост. И. Ганиев. СПб.: Диля, 2014. 272 с.

Girgas V. F. Arabic-Russian Dictionary of the Quran and Hadiths. St. Petersburg: Dilya, 2006. 928 p. (In Arab. and Russ.)

Khusainov G. B. (ed.) History of Bashkir Literature. In 6 vols. Vol. 1: The Medieval Period. Ufa: Bashkortostan Book Publ., 1990. 609 p. (In Bash.)

Khusainov G. B., Nadergulov M. Kh. (eds.) History of Bashkir Literature. Vol. 1: From Earliest Times to the $20^{\text {th }}$ Century. Ufa: Kitap, 2012. 560 p. (In Russ.)

Kireev A. N. Bashkir Oral Folk Poetry. Ufa: Bashkir State University, 1981. 232 p. (In Bash.)

Kireev A. N. Heroic Epic of the Bashkir People. Ufa: Bashkortostan Book Publ., 1970. 304 p. (In Russ.) 
Kunafin G. S. Bashkir Poetry, $19^{\text {th }}-$ Early $20^{\text {th }}$ Century: Genre, Ideological, and Artistic Features Reviewed. Ufa: Bashkortostan Academy of Sciences, Gilem, 2011. 480 p. (In Russ.)

Salikhov A. G. The Arslan-Amekachevsky (Ungarovsky) version of Edification by Miftakhetdin Akmullah. The Problems of Oriental Studies. 2020. No. 3 (89). Pp. 74-83. (In Russ.)

Salikhov A. G., Abdrafikova G. Kh., Iskandarova S. A. Munajats from Tatyshlinsky District of Bashkortostan. In: Yunusova A. B. (ed.) Archaeography of the Southern Urals: Documentary Heritage of the Russian Revolution. Conference proceedings. Ufa: Mir Pechati, 2017. Pp. 157-164. (In Russ.)
Sultangareeva R. A. (comp.) Bashkir Folklore. Vol. XV: Munajats. Ufa: Kitap, 2018. 296 p. (In Bash.)

Sultangareeva R. A. Bashkir Folklore: Semantics, Functions and Traditions. Vol. 1: Myth, Ritual, Dance, Taletelling. Shamanic, Religious, Musical Folklore. Contemporary Traditions. Ufa: Bashkirskaya Entsiklopediya, 2018. 520 p. (In Russ.)

Tuymova G. R. Religious Musical and Poetic Genres in Traditional Music of Crimean Tatars: Mawlid and Ilāh. Cand. Sc. (art studies) thesis abstract. Moscow, 2008. 22 p. (In Russ.)

Useinova S. R. Arabic religious poetry - defining and periodization problems. Vestnik of Saint Petersburg University. Asian and African Studies. 2014. No. 2. Pp. 39-52. (In Russ.) 